\title{
Assessment of stress conditions for carotenoids accumulation in Chlamydomonas reinhardtii as added-value algal products
}

\author{
Samar A. El-Mekkawi, H. S. Hussein*, S. A. Abo El-Enin and N. N. El-lbiari
}

\begin{abstract}
Background: Microalgae, the third-generation source of biofuel have invaluable bio-refineries such as carotenoids. The accumulation of carotenoids in the algal cell is based on several parameters during algal growth. Some of these parameters are irradiance and cultivation periods which figures the photoperiod during algal growth. In this work, $0.6 \mathrm{~g} / \mathrm{L}$ Chlamydomonas reinhardtii, green algae strain, was cultivated using the BG-11 medium in bubble column photobioreactor illuminated by white cool fluorescent $24 \mathrm{~h}$ per day, irradiance range 40.5-149 $\mu \mathrm{mol} . \mathrm{m}^{-2} \cdot \mathrm{s}^{-1}$, and cultivation period range 10-20 days. The carotenoids were extracted using two solvents, petroleum ether, and ethyl acetate in ratio 7:3. The carotenoids fractions were quantified using HPLC and the design expert program 8.6 was used to optimize the irradiance and cultivation period in order to gain maximum carotenoids accumulation in C. reinhardtii using response surface method.
\end{abstract}

Results: The results revealed that the optimum conditions of $C$. reinhardtii cultivation are illuminating the culture 24 $\mathrm{h}$ a day for 10 days with irradiance $149 \mu \mathrm{mol} . \mathrm{m}^{-2} . \mathrm{s}^{-1}$ producing $0.85 \mathrm{mg} / \mathrm{g}$ astaxanthin, $0.87 \mathrm{mg} / \mathrm{g}$ lutein, and 0.64 $\mathrm{mg} / \mathrm{g} \beta$-carotene, as a maximum value of accumulating carotenoids in $2.15 \mathrm{~g} / \mathrm{L}$ biomass yield.

Conclusions: High irradiance and cultivation period are two essential parameters for accumulating carotenoids in algae. Response surface method is an affordable method to optimize these parameters simultaneously via predicting a model describe the relation and analyze the results statistically. The experimental verification of results proved the model's validity. The prospective research is going to study the effect of more parameters on carotenoids accumulation in algae.

Keywords: Microalgae, Astaxanthin, lutein, $\beta$-carotene, Factorial design

\section{Background}

Microalgae are considered as an ideal source for natural carotenoids and they gather the easy and rapid growth than other unicellular microorganisms (Berman et al. 2015, Henríquez et al. 2016). Carotenoids are characterized by energetic metabolism, which ensures a variety of secondary metabolites products (Ahmed et al. 2014). Furthermore, their benefits in human health were conclusively proved, and this led to open novel uses for some carotenoids (Thomas and Kim 2013).

\footnotetext{
* Correspondence: hala.hussein21@yahoo.com Chemical Engineering \& Pilot Plant Department, National Research Centre, Dokki, Cairo 12311, Egypt
}

\section{Springer Open}

(c) The Author(s). 2019 Open Access This article is distributed under the terms of the Creative Commons Attribution 4.0 International License (http://creativecommons.org/licenses/by/4.0/), which permits unrestricted use, distribution, and reproduction in any medium, provided you give appropriate credit to the original author(s) and the source, provide a link to the Creative Commons license, and indicate if changes were made. according to their chemical structure into two types: carotene and xanthophyll. Carotene molecule as $\beta$ carotene, $\alpha$-carotene, and lycopene is a hydrocarbon chain consists of eight isoprenoid units forming a long skeleton (40 carbons) conjugated by double bonds and terminated by cyclic hydrocarbon groups (Ben Amor et al. 2017). The xanthophyll molecule is a carotene molecule with oxygenated groups that cause higher polarity than the carotene molecule (Stahl and Sies 2012). In xanthophyll, the oxygen group expresses the kind of carotenoids, e.g.; $\mathrm{OH}$ groups indicate lutein, while the oxi-groups signify 
canthaxanthin, and the combination of both designate astaxanthin (Guedes et al. 2011).

There are about 700 different chemical structures of carotenoid pigments (isomers) with perceptive colors and biological properties (Stafsnes et al. 2010). The double bonds in carotenoids molecules are making a light-absorbing for the chromophore, which confers them the characteristic of staining color yellow, red, or orange (Cardoso and Kanno KYand Carp 2017). Also, they are making them very sensitive to light, heat, and oxygen (Amorim-Carrilho et al. 2014).

Carotenoids proved their activity as an antioxidant and pro-vitamin A. Thus, they are used in pharmaceutical, nutraceutical, and cosmetic industries (Cardoso and Kanno KYand Carp 2017). B-carotene is used by dermatologists due to its ability to regenerate cells at the outer layers of the skin. It is also used in the industries of cosmetics such as in suntan, moisturizers, makeup, cleansers, and hair care products. The ability of $\beta$-carotene to protect skin from sun damage is attributed to its antioxidant property which also imparts a natural glow to the skin (Stafsnes et al. 2010). Lutein and zeaxanthin are of high valuable secondary metabolites carotenoids, acting to protect the human retina against photo-oxidative damage and macular degeneration (Sun et al. 2016). While the astaxanthin has a good effect to improve skin wrinkle, age spot size, elasticity, and skin texture (Lorenz and Cysewski 2000; Tominaga et al. 2012).

Green algae like Dunaliella, Chlorella, Haematococcus, and Chlamydomonas, can be overproducing secondary carotenoids under unusual culture conditions such as light intensity, cultivation period, salt stress, temperature, and nitrogen limitation (Fu et al. 2013; Santhosh et al. 2016). The genetic powerful with rapid growth and high biomass production at the low cost of Chlamydomonas species made them very interesting for biotechnology research to produce high-value carotenoids (Couso et al. 2012; Neupert et al. 2009). However, stress conditions should be optimized to avoid interior interactions. The response surface methodology (RSM) is one of the scientific approaches that are useful for optimizing the parameters affecting any process. Also, it is used to analyze the effects of several independent variables on the system response and to determine the optimum operating conditions within the operating specifications (Attia et al. 2014).

In this study, irradiance and cultivation period as stress conditions of carotenoids accumulation in C. reinhardtii were studied and analyzed using RSM to ensure that there is not any interaction between the parameters and the lack of fit is not significant. Finally, prediction models for carotenoids accumulation were derived analyzing the relation between the parameters and the carotenoids by mass ratio, then comparing the priorities of biomass productivity and carotenoids accumulation to obtain the maximum yield of carotenoids.

\begin{abstract}
Methods
Materials

Inoculum preparation and cultivation system

Chlamydomonas reinhardtii was isolated from the Nile

River, Egypt, at Wastewater Research Department, National

Research Centre, Egypt. Initial concentration $0.6 \mathrm{~g} / \mathrm{L}$ of $C$. reinhardtii was cultivated at a temperature $20 \pm 1{ }^{\circ} \mathrm{C}$ (293 $\pm 273 \mathrm{~K})$, aeration flow rate $1 \mathrm{~V} / \mathrm{V}$ and irradiance range $40.5-149 \mu \mathrm{mol} . \mathrm{m}^{-2} . \mathrm{s}^{-1}$ of white cool fluorescent light and the cultivation period from $10-20$ days $24 \mathrm{~h}$ per day in bubble column photobioreactor using the BG11 medium (El-Mekkawi et al. 2016). Microalgae were harvested through settling without additives (30-60 min). The sediments were collected and washed twice by distilled water, then centrifuged at $1000 \mathrm{rpm}$ for $10 \mathrm{~min}$. The algal cells were dried at $40{ }^{\circ} \mathrm{C}(313 \mathrm{~K})$ overnight (El-Mekkawi et al. 2016).
\end{abstract}

\section{Pigment extraction}

The dried algae were repeatedly extracted under stirring with a homogenizer for $5 \mathrm{~min}$ with several portions of a solution consists of petroleum ether (b.p. $40-60{ }^{\circ} \mathrm{C}$ ) $(313-333 \mathrm{~K})$ and ethyl acetate in ratio $7: 3$ at room temperature and dim light until colorless extract was obtained. The suspensions were filtered and washed with distilled water then separated using separating funnel and dried in a stream of nitrogen (Sarkar et al. 2012).

\section{Saponification}

The extracts $(25 \mathrm{~mL})$ were treated with $5 \%$ ethanolic potassium hydroxide solution $(5 \mathrm{~mL})$ and kept overnight at room temperature for complete saponification of xanthophyll esters. This solution is washed with water several times till neutrality, then separated using separating funnel and dried in a stream of nitrogen (Weissenberg et al. 1997).

\section{HPLC analysis}

Chromatographic separations were done using a reversed-phase column (Agilent TC, $\mathrm{C}_{18}$ (2), $5 \mu \mathrm{m}$ $12.5 \times 0.4 \mathrm{~cm} \mathrm{I.D.)}$. The chromatograms were monitored at $450 \mathrm{~nm}$; the mobile phase was acetonitrile, 2-propanol, ethyl acetate (40: 40: 20, $v / v / v)$; the flow rate was $0.8 \mathrm{~mL} / \mathrm{min}$; the pressure was $58-72$ bar. The dried extracts were dissolved in the solution of extraction $(1 \mathrm{~mL})$, filtered through a $0.45 \mu \mathrm{m}$ membrane disc $(4.6 \times 250 \mathrm{~mm})$ and injected into the chromatograph (injection volume $10 \mu \mathrm{L}$ ). The column was regenerated by washing with 2-propanol after analysis and equilibrated with the mobile phase (Weissenberg et al. 1997; Ligor et al. 2014). 
RSM

The light intensity and the period of cultivation are considered the most significant parameters affecting the accumulation of carotenoids in phototrophic algae (Varela et al. 2015; Wahidin et al. 2013). The range of the examined irradiance was $40.5-149 \mu \mathrm{mol} . \mathrm{m}^{-2} . \mathrm{s}^{-1}$. The selected range of cultivation period was 10-20 days. The response surface methodology (RSM) was applied as a suitable route for optimizing the interactive effect of irradiance $(I)$ and the cultivation period $(T)$ on the carotenoids concentration. The experimental results were statistically analyzed and modeled using the RSM according to Eq. 1 (Montgomery 2003), which was applied using Design Expert-6.0.8 software during a trial period. The extent of the fit of the model was evaluated using the coefficient of determination and analysis of variance (ANOVA).

$$
\begin{aligned}
Y= & a_{0}+a_{1} X_{1}+a_{2} X_{2}+a_{11} X_{1}^{2}+a_{22} X_{2}^{2} \\
& +a_{12} X_{1} X_{2}
\end{aligned}
$$

where

$a_{0}=$ the regression constant;

$a_{0}, a_{1}, a_{2}, a_{11}, a_{22}, a_{12}=$ regression coefficients; and

$X_{1}$ and $X_{2}=$ independent variables investigated here.

\section{Results}

The effects of light intensity and cultivation period were studied as two independent variables affecting carotenoids concentration in a total of 13 experiments in accordance with a $2^{2}$ complete factorial design as shown in Table 1 . The data were analyzed using Design Expert 6.0.8 software and by applying the RSM. Tables 2 and 3 describes the ANOVA for the response surface of a quadratic model for astaxanthin and $\beta$-carotene responses, and 2FI model for lutein response. The analysis of astaxanthin response yielded two linear coefficients (A, B), two quadratic coefficients $\left(\mathrm{A}^{2}, \mathrm{~B}^{2}\right)$, and one cross-product coefficient for the full model. The statistical analysis of astaxanthin content response revealed that the regression coefficient $\left(R^{2}\right)$ was 0.99 , whereas the predicted $R^{2}$ was 0.95 and the adjusted $R^{2}$ was 0.98 with a coefficient of variation (CV) 10.53. The regression equation for astaxanthin content in terms of coded variables is as follows:

$$
\begin{aligned}
\text { Astaxanthincontent } & =0.22-(0.0 .98 \times A) \\
& -(0.33 \times B)+\left(0.30 \times A^{2}\right) \\
& -\left(0.13 \times B^{2}\right)-(0.025 \times A \times B)
\end{aligned}
$$

The regression equation of the biomass yield response in terms of the actual variables is as follows:

$$
\begin{aligned}
\text { Astaxanthin, } m g / g= & 3.28829-(0.26854 \times I)-(0.20739 \times T) \\
& +\left(0.018805 \times I^{2}\right)+\left(0.005 \times T^{2}\right) \\
& -(0.001 \times I \times T)
\end{aligned}
$$

\begin{tabular}{|c|c|c|c|c|c|c|c|c|}
\hline \multirow[t]{2}{*}{ Run } & \multirow{2}{*}{$\left(\mu \mathrm{mol} . \mathrm{m}^{-2} \cdot \mathrm{s}^{-1}\right)$} & \multirow{2}{*}{$\begin{array}{l}\mathrm{C} \\
\text { (mg/ } \\
\mathrm{L})\end{array}$} & \multicolumn{2}{|c|}{ Astaxanthin (mg/g) } & \multicolumn{2}{|c|}{ Lutein (mg/g) } & \multicolumn{2}{|c|}{$\underline{\beta}$-carotene (mg/g) } \\
\hline & & & Actual & Predicted & Actual & Predicted & Actual & Predicted \\
\hline 1 & 40.50 & 10.00 & 1.10 & 1.04 & 1.54 & 1.57 & 0.88 & 0.85 \\
\hline 2 & 149.00 & 10.00 & 0.90 & 0.90 & 0.80 & 0.83 & 0.65 & 0.64 \\
\hline 3 & 40.50 & 20.00 & 0.48 & 0.44 & 0.99 & 1.00 & 0.34 & 0.35 \\
\hline 4 & 149.00 & 20.00 & 0.18 & 0.20 & 0.42 & 0.43 & 0.18 & 0.21 \\
\hline 5 & 18.03 & 15.00 & 0.90 & 0.96 & 1.42 & 1.42 & 0.60 & 0.61 \\
\hline 6 & 171.47 & 15.00 & 0.70 & 0.68 & 0.50 & 0.50 & 0.37 & 0.36 \\
\hline 7 & 94.75 & 7.93 & 0.90 & 0.93 & 1.35 & 1.31 & 0.85 & 0.87 \\
\hline 8 & 94.75 & 22.07 & 0 & 0.01 & 0.62 & 0.61 & 0.23 & 0.21 \\
\hline 9 & 94.75 & 15.00 & 0.30 & 0.22 & 0.90 & 0.96 & 0.28 & 0.30 \\
\hline 10 & 94.75 & 15.00 & 0.20 & 0.22 & 0.99 & 0.96 & 0.31 & 0.30 \\
\hline 11 & 94.75 & 15.00 & 0.20 & 0.22 & 0.97 & 0.96 & 0.30 & 0.30 \\
\hline 12 & 94.75 & 15.00 & 0.20 & 0.22 & 0.98 & 0.96 & 0.32 & 0.30 \\
\hline 13 & 94.75 & 15.00 & 0.19 & 0.22 & 0.98 & 0.96 & 0.29 & 0.30 \\
\hline
\end{tabular}

The normal plots of the residuals of this model are shown in Fig. 1. and the surface plot and contour of astaxanthin is shown in Fig. 2. The analysis of lutein response yielded two linear coefficients (A, B) and one cross-product coefficient for the full model. The $R^{2}$ was 0.99 , the adjusted $R^{2}$ was 0.99 , the predicted $R^{2}$ was 0.98 ,

Table 1 Experimental data for five levels of the two-factor response surface analysis 
Table 2 ANOVA results for the responses model

\begin{tabular}{|c|c|c|c|c|c|c|}
\hline \multirow[t]{2}{*}{ Source } & \multicolumn{2}{|c|}{ Astaxanthin response } & \multicolumn{2}{|c|}{ Lutein response } & \multicolumn{2}{|c|}{$\beta$-carotene response } \\
\hline & $F$ value & Prob $>$ F & $F$ value & Prob $>$ F & $F$ value & Prob $>F$ \\
\hline Model & 126.08 & $<0.0001$ & 408.21 & $<0.0001$ & 247.29 & $<0.0001$ \\
\hline A & 29.77 & 0.0009 & 776.84 & $<0.0001$ & 120.39 & $<0.0001$ \\
\hline B & 332.85 & $<0.0001$ & 440.77 & $<0.0001$ & 846.27 & $<0.0001$ \\
\hline$A^{2}$ & 246.01 & $<0.0001$ & - & - & 113.07 & $<0.0001$ \\
\hline$B^{2}$ & 43.06 & 0.0003 & - & - & 187.93 & $<0.0001$ \\
\hline$A \times B$ & 1.02 & 0.3470 & 7.01 & 0.0266 & 2.26 & 0.1764 \\
\hline Lack of fit & 1.48 & 0.3463 & 0.68 & 0.6641 & 4.66 & 0.0856 \\
\hline
\end{tabular}

and the CV was 3.45. The regression equation for lutein content in terms of coded variables is as follows:

$$
\begin{aligned}
\text { Luteincontent }= & 0.96-(0.33 \times A)-(0.25 \times B) \\
& +(0.044 \times A \times B)
\end{aligned}
$$

The regression equation of the biomass yield response in terms of the actual variables is as follows:

$$
\text { Luteincontent, } \begin{aligned}
m g / g & =2.49444-(0.11425 \times I) \\
& -(0.064388 \times T) \\
& +(0.0022 \times I \times T)
\end{aligned}
$$

The normal plots of the residuals of this model are shown in Fig. 3. and the surface plot and contour of lutein is shown in Fig. 4.

The analysis of the quadratic model of $\beta$-carotene response yielded two linear coefficients (A, B), two quadratic coefficients $\left(\mathrm{A}^{2}, \mathrm{~B}^{2}\right)$, and one cross-product coefficient for the full model. The statistical analysis of $\beta$-carotene content response revealed that both the $R^{2}$ and the adjusted $R^{2}$ was 0.99 , whereas the predicted $R^{2}$ was 0.97 and the $C V$ was 5.32. The regression equation for $\beta$-carotene content in terms of coded variables is as follows:

$$
\begin{aligned}
\beta \text {-carotenecontent } & =0.30-(0.098 \times A)-(0.24 \times B) \\
& +\left(0.092 \times A^{2}\right)+\left(0.12 \times B^{2}\right) \\
& -(0.017 \times A \times B)
\end{aligned}
$$

The regression equation of the biomass yield response in terms of the actual variables is as follows:

$$
\begin{aligned}
\beta \text {-caratene, } m g / g= & 2.61778-(0.11613 \times I)-(0.19633 \times T) \\
& +\left(0.0058 \times I^{2}\right)+\left(0.0048 \times T^{2}\right) \\
& -(0.0008 \times I \times T)
\end{aligned}
$$

The normal plots of the residuals of this model are shown in Fig. 5. and the surface plot and contour of $\beta$ carotene is shown in Fig. 6.

The predicted optimum conditions of $C$. reinhardtii cultivation using the statistical models are two routes, the first is $40.5 \mu \mathrm{mol} . \mathrm{m}^{-2} . \mathrm{s}^{-1}$ irradiance and 10 days cultivation period, whereas the second route, is 149 $\mu$ mol. $\mathrm{m}^{-2} . \mathrm{s}^{-1}$ for 10 days. In Table 4 , the statistical analysis of the predicted values based on these solutions were verified. The biomass yield after 10 days cultivation was $1.7 \mathrm{~g} / \mathrm{L}$ at $40.5 \mu \mathrm{mol} . \mathrm{m}^{-2} . \mathrm{s}^{-1}$ and $2.15 \mathrm{~g} / \mathrm{L}$ at 149 $\mu \mathrm{mol} . \mathrm{m}^{-2} \cdot \mathrm{s}^{-1}$.

\section{Discussion}

Irradiances at $100-200 \mu \mathrm{mol} . \mathrm{m}^{-2} . \mathrm{s}^{-1}$ are commonly used for microalgal production of phototrophic cultivation (Zhao and $\mathrm{Su} 2014$ ). Optimum light requirements vary with the microalgal species (Minhas et al. 2016). Light intensity as well as cultivation time, that figures the photoperiod, affect biomass, and other metabolites (Sey-

\begin{tabular}{|c|c|c|c|c|c|}
\hline Solution & Irradiance, $\mu \mathrm{mol} . \mathrm{m}^{-2} \cdot \mathrm{s}^{-1}$ & Time, day & Astaxanthin, mg/g & Lutein, mg/g & $\beta$-carotene, mg/g \\
\hline 1 & 40.5 & 10 & 1.04 & 1.57 & 0.85 \\
\hline 2 & 149 & 10 & 0.85 & 0.87 & 0.64 \\
\hline
\end{tabular}
fabadi et al. 2011; Khoeyi et al. 2012). However, there is no sufficient information about the interactive effect of irradiance (I) and cultivation period (T) on the carotenoid content for $C$. reinhardtii; thus, RSM is used to analyze this interaction if exist.

The statistical analysis of each astaxanthin response, lutein response, and $\beta$-carotene response revealed that the predicted $R^{2}$ is in reasonable agreement with the adjusted $R^{2}$. The values of Prob $>\mathrm{F}$ less than 0.05

Table 3 The optimum conditions for carotenoids 


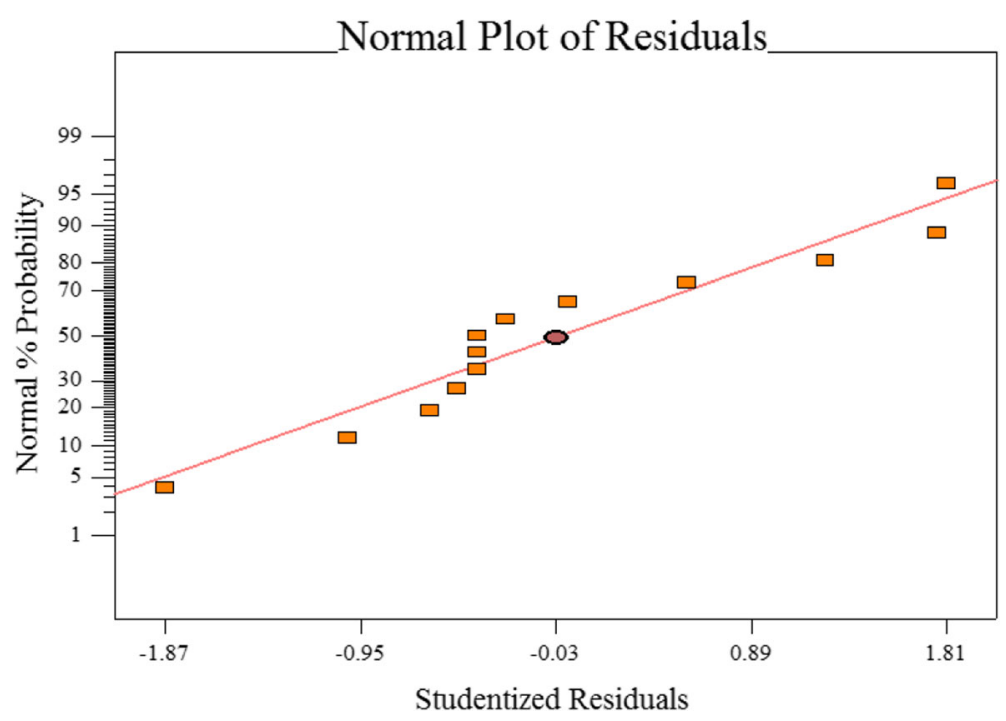

Fig. 1 The normal plot of residuals of astaxanthin model

indicating the model terms are significant, whereas the lack of fit of the three responses are not significant that indicate that the model can accurately predict the relationships between the reaction factors within the selected range. High variance is noticed as each coefficient of variation (C.V.) is greater than one indicating that the data points are very spread out from the mean, and from one another.

The analysis revealed that the optimum conditions required for the maximum carotenoid content are irradiance
$40.5 \mu \mathrm{mol} . \mathrm{m}^{-2} . \mathrm{s}^{-1}$ and 10 days cultivation period. The results predicted via the models with $95 \%$ confidence level were $1.04 \mathrm{mg} / \mathrm{g}$ astaxanthin, $1.57 \mathrm{mg} / \mathrm{g}$ lutein, and 0.85 $\mathrm{mg} / \mathrm{g} \beta$-carotene. At the conditions of $149 \mu \mathrm{mol} . \mathrm{m}^{-2} . \mathrm{s}^{-1}$ irradiance and 10 days cultivation period, the results at $95 \%$ confidence level were $0.85 \mathrm{mg} / \mathrm{g}$ astaxanthin, 0.87 $\mathrm{mg} / \mathrm{g}$ lutein, and $0.64 \mathrm{mg} / \mathrm{g} \beta$-carotene. However, according to the biomass yield that increases with increasing light intensity; the second solution is preferred as a consequence of increasing the total weight of carotenoids.

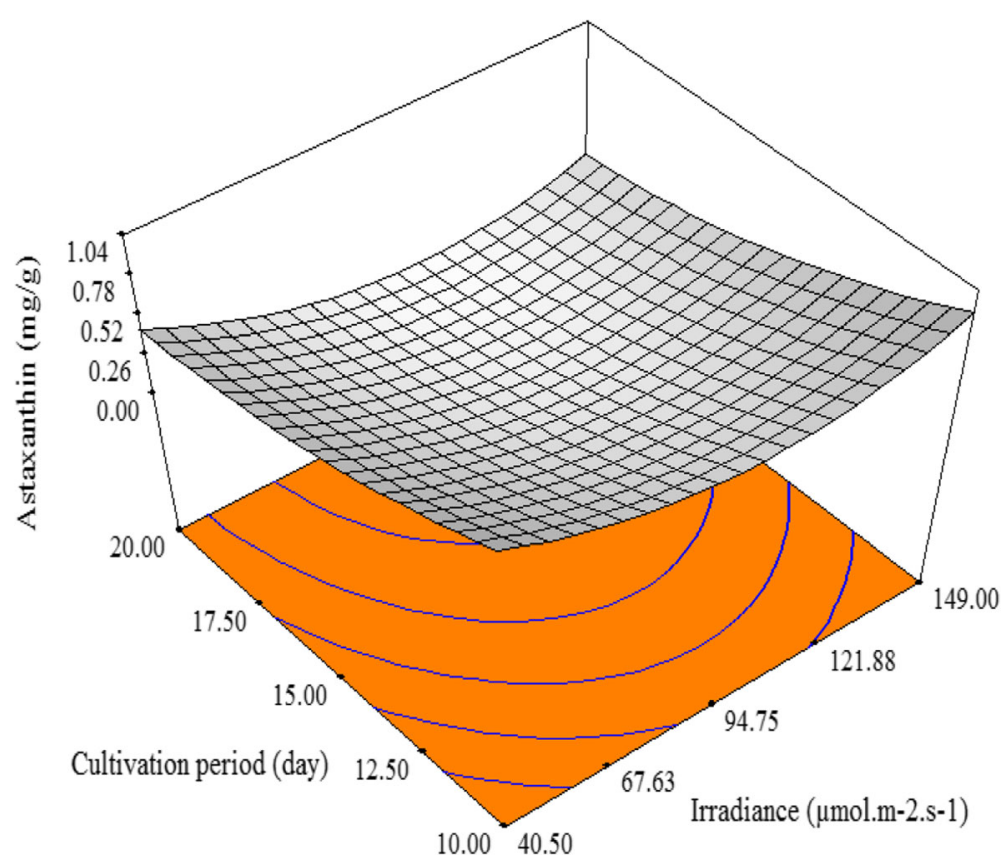

Fig. 2 The RSM model graph of astaxanthin content 


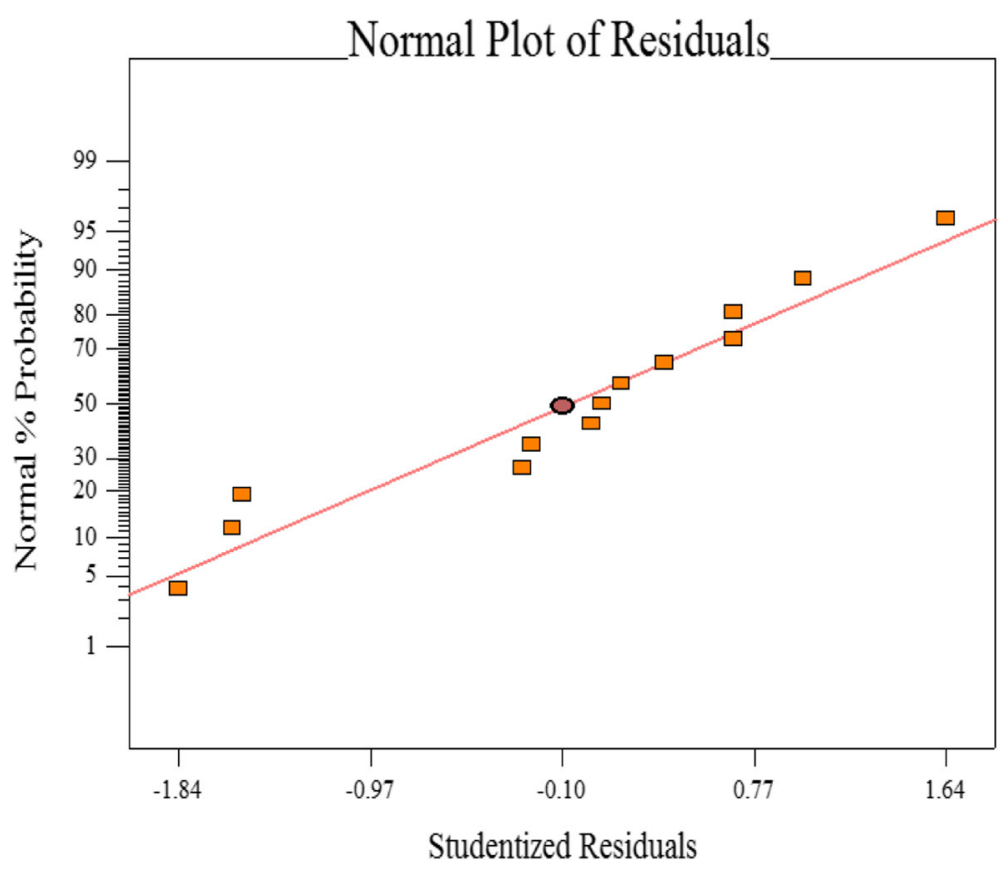

Fig. 3 The normal plot of lutein model

The statistical studies tackled with optimizing the stress conditions are rare. However, the results are in agreement with that found describing the effect of high light intensity during the exponential phase. Increasing light intensity caused an increase in astaxanthin in Haematococcus pluvialis (Del Campo et al. 2004), the same was recorded for Scenedesmus sp. that accumulate $0.59 \mathrm{mg} / \mathrm{g}$ under stress conditions of high irradiance
(Peng et al. 2012). In this work, astaxanthin content increased by $6 \%$ of total carotenoids as irradiance increased from $40.5 \mu \mathrm{mol} . \mathrm{m}^{-2} . \mathrm{s}^{-1}$ to $149 \mu \mathrm{mol} . \mathrm{m}^{-2} . \mathrm{s}^{-1}$, (Xie et al. 2013) where high light intensity resulted in lutein content reduction in Scenedesmus sp. Besides astaxanthin, $\beta$-carotene content was also increased by $2 \%$ of total carotenoids at light intensity increased from 40.5 $\mu \mathrm{mol} . \mathrm{m}^{-2} . \mathrm{s}^{-1}$ to $149 \mu \mathrm{mol} . \mathrm{m}^{-2} . \mathrm{s}^{-1}$.

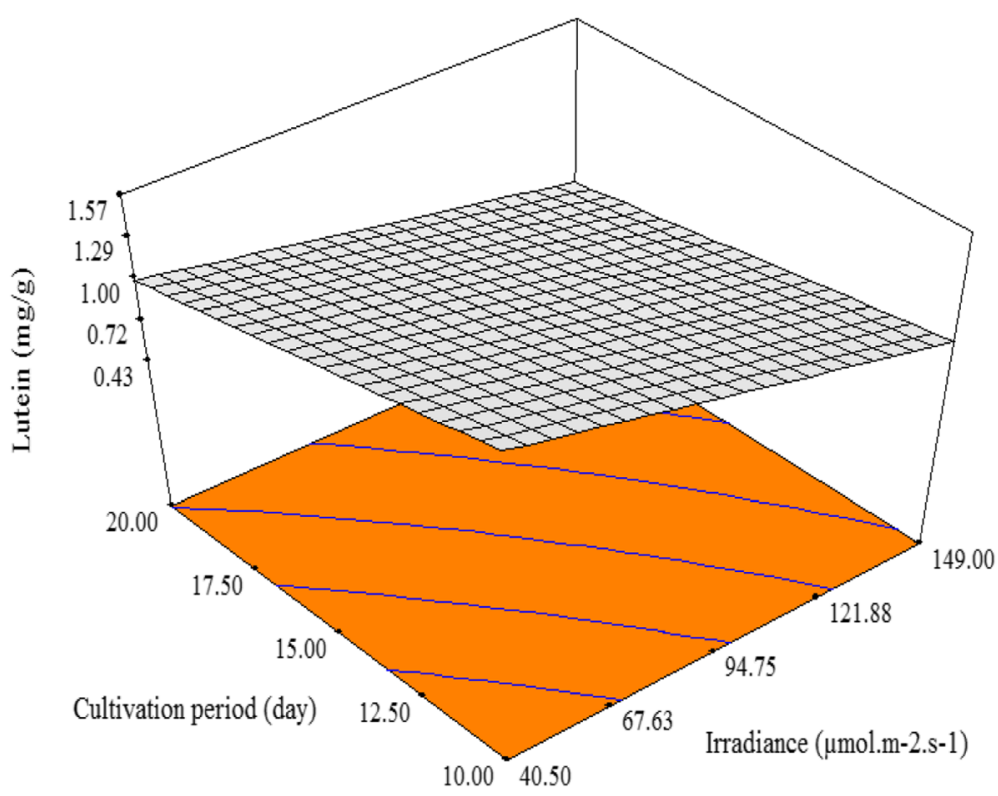

Fig. 4 The RSM model graph of lutein content 


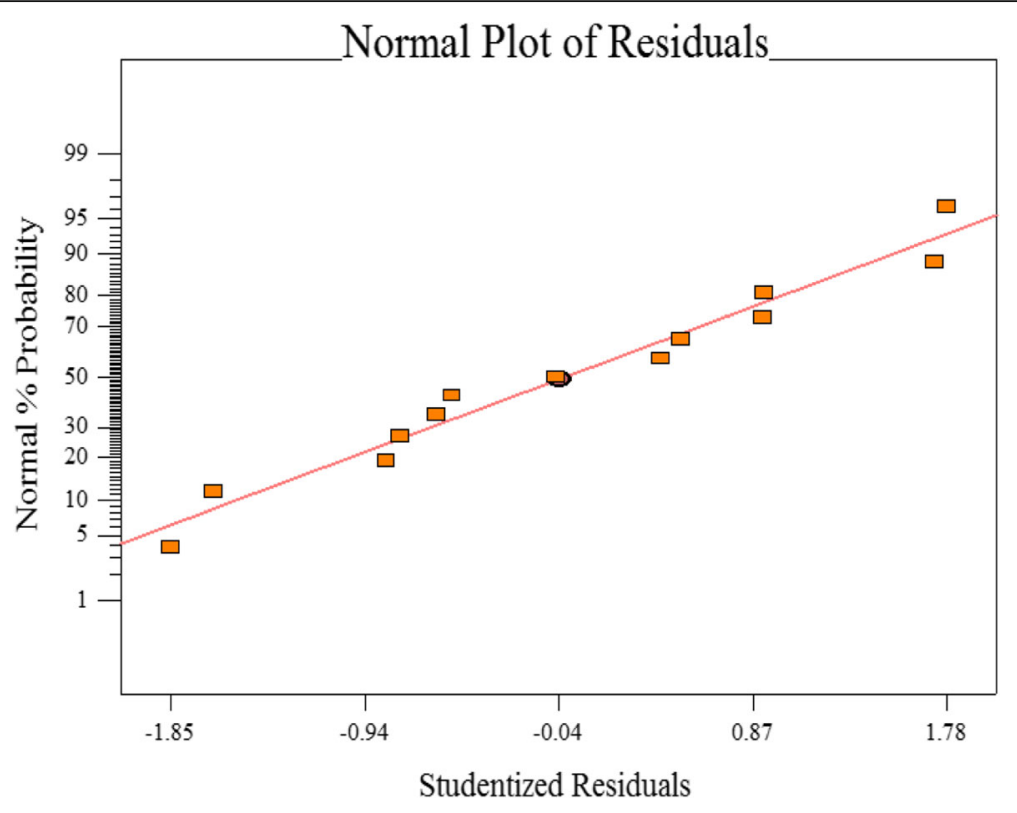

Fig. 5 The normal plot of $\beta$-carotene model

Formation of each primary $\beta$-carotene and secondary carotene is affected by high as well as by low light intensity as shown in Fig. 6 as a consequence to the existence of photosynthesis under both levels of light intensity (El-Baz et al. 2002). At low irradiance, fewer oxygen radicals are generated, whereas under high irradiance cells are unable to utilize all the energy that is generated which implies the lutein decreasing for high irradiance as shown in Fig. 4 this may due to the functional group in lutein molecule (Guedes et al. 2011). However; high energy results from high irradiance activates more oxygen molecules that are essential for the oxi-group of astaxanthin, leading to the formation of astaxanthin (Guedes et al. 2011; Mata-Goméz et al. 2014).

\section{Conclusions}

As the high irradiance and cultivation period are two essential parameters for accumulating oil in algae to produce biofuel, these parameters are also essential for the accumulation of carotenoids which are added-value for

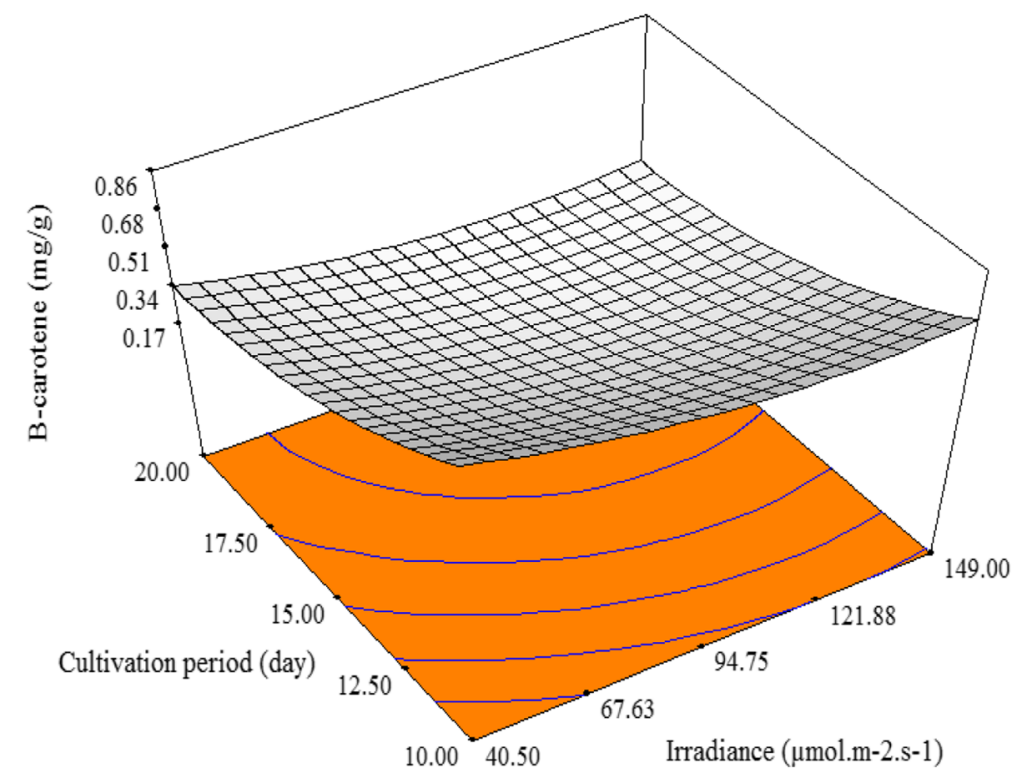

Fig. 6 The RSM model graph of $\beta$-carotene content 
Table 4 Statistical analysis of the predicted solutions

\begin{tabular}{|c|c|c|c|c|c|c|c|}
\hline & Prediction & $\begin{array}{l}\text { SE } \\
\text { mean }\end{array}$ & $\begin{array}{l}95 \% \\
\mathrm{Cl} \\
\text { low }\end{array}$ & $\begin{array}{l}95 \% \\
\mathrm{Cl} \\
\text { high }\end{array}$ & $\begin{array}{l}\text { SE } \\
\text { pred. }\end{array}$ & $\begin{array}{l}95 \% \\
\mathrm{Pl} \\
\text { low }\end{array}$ & $\begin{array}{l}95 \% \\
\text { Pl } \\
\text { high }\end{array}$ \\
\hline \multicolumn{8}{|l|}{ Solution 1} \\
\hline Astaxanthin & 1.04 & 0.04 & 0.94 & 1.13 & 0.064 & 0.89 & 1.19 \\
\hline Lutein & 1.57 & 0.025 & 1.51 & 1.63 & 0.041 & 1.48 & 1.66 \\
\hline$\beta$-carotene & 0.85 & 0.018 & 0.81 & 0.89 & 0.029 & 0.78 & 0.92 \\
\hline \multicolumn{8}{|l|}{ Solution 2} \\
\hline Astaxanthin & 0.85 & 0.037 & 0.76 & 0.93 & 0.063 & 0.7 & 0.99 \\
\hline Lutein & 0.87 & 0.023 & 0.82 & 0.93 & 0.041 & 0.78 & 0.96 \\
\hline$\beta$-carotene & 0.64 & 0.017 & 0.6 & 0.67 & 0.028 & 0.57 & 0.7 \\
\hline
\end{tabular}

biofuel. The response surface method is an effective method to optimize the parameters simultaneously by predicting a model to describe the relation and analyze the results statistically. The results of this research recommended the cultivation of C. reinhardtii for 10 days at $149 \mu \mathrm{mol} . \mathrm{m}^{-2} . \mathrm{s}^{-1}$ produce $0.85 \mathrm{mg} / \mathrm{g}$ astaxanthin, 0.87 $\mathrm{mg} / \mathrm{g}$ lutein, and $0.64 \mathrm{mg} / \mathrm{g} \beta$-carotene. The prospective research is going to study the effect of different wavelengths and cultivation period on carotenoids amount.

\section{Abbreviations}

A: Irradiance coefficient; $a_{0}$ : The regression constant; $a_{0}, a_{1}, a_{2}, a_{11}, a_{22}$ $a_{12}$ : Regression coefficients; B: Time coefficient; C.V.: Coefficient of variation; Prob > F: Probability function; $R^{2}$ : Regression coefficient; RSM: Response surface methodology; $X_{1}$ and $X_{2}$ : Independent variables

\section{Acknowledgements}

The authors would like to express their appreciation to the National Research Centre Fund for financial support through the Project entitled "Extraction of Bioactive Compounds from Microalga."

\section{Authors' contributions}

All authors participated in the development and implementation of the research plan and subsequently written it. All authors read and approved the final manuscript.

\section{Funding}

This work was done in the National Research Centre, Egypt that has funded all the experimental work.

\section{Availability of data and materials}

Not applicable

\section{Ethics approval and consent to participate}

Not applicable

\section{Consent for publication}

Not applicable

\section{Competing interests}

The authors declare that they have no competing interests
Received: 7 March 2019 Accepted: 23 July 2019

Published online: 06 August 2019

\section{References}

Ahmed F, Fanning K, Netzel M, Turner W, Li Y, Schenk PM (2014) Profiling of carotenoids and antioxidant capacity of microalgae from subtropical coastal and brackish waters. Food Chem. 165(15):300-306

Amorim-Carrilho KT, Cepeda A, Fente C, Regal P (2014) Review of methods for analysis of carotenoids. Trends Anal Chem. 56:49-73

Attia NK, Gadalla AG, El-lbiari NN, El-Araby R, El-Diwani Gl (2014) Studying the ultrasonic assiste transesterification of castor oil by using factorial design for optimization of biodiesel production. AFINIDAD LXXI. 566

Ben Amor F, Elleuch F, Ben Hlima H, Garnier M, Saint-Jean B, Barkallah M, Pichon C, Abdelkafi S, Fendri I (2017) Proteomic Analysis of the Chlorophyta Dunaliella New Strain AL-1 Revealed Global Changes of Metabolism during High Carotenoid Production. Mar Drugs 15:293

Berman J, Zorrilla-López U, Farré G, Zhu C, Sandmann G, Twyman RM, Capell T, Christou P (2015) Nutritionally important carotenoids as consumer products. Phyto Chem Rev. 14:727-743

Cardoso LA, Kanno KY, Carp SG (2017) Microbial production of carotenoids-a review. Afr J Biotechnol. 16(4):139-146

Couso I, Vila M, Vigara J, Cordero BF, Vargas MA, Guez HR, Leon R (2012) Synthesis of carotenoids and regulation of the carotenoid biosynthesis pathway in response to high light stress in the unicellular microalga Chlamydomonas reinhardtii. Eur J Phycol. 47(3):223-232

Del Campo JA, Rodríguez H, Moreno J, Vargas MA, Rivas J, Guerrero MG (2004) Accumulation of astaxanthin and lutein in Chlorella zofingiensis (Chlorophyta). App Microbiol Biotechnol. 64:848-854

El-Baz FK, Aboul-Enein MA, El-Baroty GS, Youssef AM, Abd El-Baky HH (2002) Accumulation of antioxidant vitamins in Dunaliella salina. Online J Biol Sci. 2:220-223

El-Mekkawi SA, El-Ibiari NN, El-Ardy OA, Abelmonem NM, Elahwany AH (2016) Optimum Photobioreactor Design via Optimizing Cultivation Conditions of Microcystis aeruginosa. Res J Pharm Biol Chem Sci. 7(5):303-3011

Fu W, Guðmundsson O, Paglia G, Herjólfsson G, Andrésson OS, Palsson BO, Brynjólfsson S (2013) Enhancement of carotenoid biosynthesis in the green microalga Dunaliella salina with light-emitting diodes and adaptive laboratory evolution. Appl Microbiol Biotechnol. 97:2395-2403

Guedes AC, Amaro HM, Malcata FX (2011) Microalgae as sources of carotenoids. Mar Drugs. 9:625-644

Henríquez V, Escobar C, Galarza J, Gimpel J (2016) Carotenoids in microalgae. In: Carotenoids in Nature. Springer International Publishing, pp 219-237

Khoeyi ZA, Seyfabadi J, Ramezanpour Z (2012) Effect of light intensity and photoperiod on biomass and fatty acid composition of the microalgae Chlorella vulgaris. Aquac Int. 20:41-49

Ligor M, Kováč ová J, Gadzała Kopciuch RM, Studzin'ska S, Sz B, Lehotay J, Buszewski B (2014) Study of RP HPLC Retention Behaviours in Analysis of Carotenoids. Chromatographia. 77:1047-1057

Lorenz RT, Cysewski GR (2000) Commercial potential for Haematococcus microalgae as a natural source of Astaxanthin. Trends Biotechnology. 18(4): 160-167

Mata-Goméz LC, Montañes JC, Méndez-Zavala A, Aguilar C (2014) Biotechnological production of carotenoids by yeasts: an overview. Microb Cell Fact. 13

Minhas AK, Hodgson P, Barrow CJ, Adholeya A (2016) A review on the assessment of stress conditions for simultaneous production of microalgal lipids and carotenoids. Front Microbiol. 7:546

Montgomery DC (2003) Introduction to factorial design, In: Design and Analysis of Experiments, fifth ed. By John Wiley and Sons Inc, pp 170-228

Neupert J, Karcher D, Bock R (2009) Generation of chlamydomonas strains that efficiently express nuclear transgenes. Plant J 57:1140-1150

Peng J, Yin K, Yuan JP Cao GX, Xue M, Wu CF, Wang J-H (2012) Characterization of a newly isolated green microalga Scenedesmus sp. as a potential source of biodiesel. Afr J Biotechnol. 11:16083-16094

Santhosh S, Dhandapani R, Hemalatha N (2016) Bioactive compounds from microalgae and its different applications-a review. Adv Appl Sci Res. 7(4):153-158

Sarkar CR, Lima D, Bhagawati B, Goswami BC (2012) A comparative study of carotenoid extraction from algae in different solvent systems. Asian J Plant Sci Res. 2(4):546-549 
Seyfabadi J, Ramezanpour Z, Khoeyi ZA (2011) Protein, fatty acid, and pigment content of Chlorella vulgaris under different light regimes. J Appl Phycol. 23:721-726

Stafsnes MH, Josefsen KD, Andersen GK, Valla S, Ellingsen TE, Bruheim P (2010) Isolation and characterization of marine pigmented bacteria from Norwegian coastal waters and screening for carotenoids with UVA-blue light-absorbing properties. J Microbiol. 48(1):16-23

Stahl W, Sies H (2012) Photoprotection by dietary carotenoids: concept, mechanisms, evidence and future development. Mol Nutr Food Res. 56(2):287-295

Sun Z, Li T, Zhou Z, Jiang Y (2016) Microalgae as a source of lutein: chemistry, biosynthesis, and carotenogenesis. Adv Biochem Eng Biotechnol. 153:37-58

Thomas NV, Kim SK (2013) Beneficial effects of marine algal compounds in cosmeceuticals. Mar Drugs. 11(1):146-164

Tominaga K, Hongo N, Karato M, Yamashita E (2012) Cosmetic benefits of astaxanthin on humans' subjects. Acta Biochim Pol. 59(1):43-47

Varela JC, Pereira H, Vila M, Leon R (2015) Production of carotenoid by microalgae: achievements and challenges. Photosynth Res. 125(3):423-436

Wahidin S, Idris A, Shaleh SRM (2013) The influence of light intensity and photoperiod on the growth and lipid content of microalgae Nannochloropsis sp. Bioresour Technol. 129:7-11

Weissenberg M, Levy A, Schaeffler I, Menagem E, Barzilai M (1997) Rapid Isocratic HPLC Analysis of Beta-Carotene in Red Peppers (Capsicum annuum L.) and Food Preparations. Chromatographia. 46:7-8

Xie Y, Ho SH, Chen CNN, Chen CY, Ng IS, Jing KJ, Chang JS, Lu Y (2013) Phototrophic cultivation of a thermo-tolerant Desmodesmus $s p$. for lutein production: effects of nitrate concentration, light intensity, and fed-batch operation. Bioresour Technol. 144:435-444

Zhao B, Su Y (2014) Process effect of microalgal-carbon dioxide fixation and biomass production: a review. Renew Sust Ener Rev. 31:121-132

\section{Publisher's Note}

Springer Nature remains neutral with regard to jurisdictional claims in published maps and institutional affiliations.

\section{Submit your manuscript to a SpringerOpen ${ }^{\circ}$ journal and benefit from:}

- Convenient online submission

- Rigorous peer review

- Open access: articles freely available online

- High visibility within the field

- Retaining the copyright to your article

Submit your next manuscript at $\boldsymbol{\nabla}$ springeropen.com 